\title{
Literature Review on Unnatural Narrative Theory
}

\author{
Sufen $\mathrm{Wu}$ \\ Faculty of English Language and Culture, Guangdong University of Foreign Studies \\ No. 2, Baiyun Avenue, Baiyun District, \\ Guangzhou City, Guangdong Province, China \\ Tel: 86-13535378528Ｅ-mail: $1477263803 @ q q . c o m$
}

Received: October 18, 2021 Accepted: November 12, 2021 Published: November 17, 2021

doi: 10.5296/jsss.v8i2.18999

URL: https://doi.org/10.5296/jsss.v8i2.18999

\begin{abstract}
Unnatural narrative becomes a popular theory in literary criticism. In 2016, No. 4 issue of Style is a special issue on Brian Richardson's Target Essay "Unnatural Narrative Theory". Narratologists such as Marie-Laure Ryan, Shen Dan, and James Phelan have responded actively to this new paradigm in narrative theory. In spite of its popularity, unnatural narrative remains controversial because of its diversified definitions, the hard-to-identified manifestations of unnaturalness, and its various interpretive strategies. Accordingly, this paper tries to comb the existing literature and provide a systematic review on the definitions, the manifestations, and the interpretive strategies of unnatural narrative theory.
\end{abstract}

Keywords: unnatural narrative, manifestations of unnaturalness, interpretive strategies of unnatural narrative

\section{Introduction}

Unnatural narrative is a newly-developed theory in the recent two decades. American narratologist Herman (2013) observes that unnatural narratology has become "an emergent strand of work in narrative theory" (p. ix). In this new field, great contributions have been made by such specialists as Jan Alber, Brian Richardson, Henrik Skov Nielsen, Rüdiger Heinze, Stefan Iversen, Maria Mäkelä, and Per Krogh Hansen. They make unnatural narrative prevalent enough to warrant scholars' attention. As such, increasing journal papers and dissertations are related to this emerging theory.

Despite its popularity, quite a few scholars still hold a not-so-positive attitude toward it because there is no agreed standard against which to judge what is unnatural narrative. Such being the case, it is urgent to carry out a scientific and systematic review on this emerging 
theory. Specifically, this review paper aims to delineate the diversified definitions of unnatural narrative, the manifestations of unnaturalness, and the interpretive strategies of unnatural narrative, hoping to make a scientific review on the theory.

\section{Literature Review}

\subsection{Definition of Unnatural Narrative}

Among the aforementioned theorists, Alber is believed to be "the first critic to systematically define the term 'unnatural' with reference to narratives" (Alber \& Heinze, 2011, p. 212). Alber (2009) claims that unnatural means "physically, logically, or humanly impossible scenarios and events. The impossibility is in accordance with the known laws governing the physical world, accepted principles of logic and standard human limitations of knowledge or ability" (p. 80). Whereas Richardson (2015), another important representative of unnatural narrative, holds the following view:

$[\mathrm{A}] \mathrm{n}$ unnatural narrative is one that contains significant anti-mimetic events, characters, settings, or frames. By antimimetic, I mean representations that contravene the presuppositions of nonfictional narratives, violate mimetic conventions and the practices of realism, and defy the conventions of existing, established genres. (p. 3, italics original)

In order to better expatiate the meaning of "antimimetic", Richardson points out the difference among mimetic texts, non-mimetic texts, and antimimetic texts. The first one refers to the fictions which aim to correspond to real experiences in the world; the second one equals to the narratives such as fairy tales that follow non-realistic conventions; and the last one means the texts that are clearly and strikingly impossible in the real world.

Other scholars also present their definitions. To name a few, Iversen (2013) ties the notion of the unnatural to narratives that "present the reader with clashes between the rules governing a storyworld and scenarios or events producing or taking place inside this storyworld - clashes that defy easy explanations" (p. 103). And Nielsen (2013) elucidates what is not a natural narrative posed by Monika Fludernik and confines the notion of unnatural narratives to "a subset of fictional narratives that - unlike realistic and mimetic narratives - cue the reader to employ interpretational strategies that are different from those she employs in nonfictionalized, conversational storytelling situations" (p. 72).

From above, it can be seen that the definitions concerning unnatural narrative are varied and diverse, which Alber and Heinze believe results from the hybridity of unnatural narratology. They claim it is "not a homogenous school of thought", but "a multifarious, hybrid, and heteroglossic movement that allows for various different perspectives on and definitions of the unnatural" (Alber \& Heinze, 2011, p. 8-9). Indeed, its multiface, hybridity, and heteroglossia allow scholars to delve into different aspects of unnatural narrative, including unnatural characters, unnatural spaces, unnatural time lines, unnatural emotions, unnatural minds, unnatural metalepses, unnatural acts of narration, and unnatural narrators. 


\subsection{Manifestations of Unnaturalness}

As for unnatural characters, Alber (2016), in Unnatural Narrative: Impossible Worlds in Fiction and Drama, classifies it into 5 general categories, they are blends of humans and animals, dead characters, robot-like humans and human-like robots, metamorphoses and transforming figures, and multiple coexisting versions of the same character. For example, the female character Fevvers in Angela Carter's novel Nights at the Circus is a blend of human and animal. Fevvers looks like a human but has a pair of wings and can fly. And Susie Salmon in Alice Sebold's novel The Lovely Bones is a pointed example of dead characters. Susie is murdered and she narrates her story from heaven. It should be noted that dead characters can trace back to earlier literature such as Shakespeare's Hamlet. In this play, King Hamlet is dead but his ghost can interact with his son. As for robot-like humans and human-like robots, Alber (2016) states that they deconstruct "our real-world knowledge of human beings" (p. 123). To name a few, Derek in Carly Churchill's play Blue Kettle loses control over his utterances and repeats the words - "blue" and "kettle" - like "malfunctioning robots" (Alber, 2016, p. 124). In terms of metamorphoses and transforming figures, Gregor Samsa in Kafka's short story "Metamorphosis" is a proper instance. One morning Gregor finds himself transformed into a giant insect-like creature.

From the examples mentioned above, it can be observed that unnatural characters cannot be categorized simply as Forster's "flat" or "round" characters. Neither can they be classified merely as Pfister's "static" or "dynamic" characters. Rather, they are artificial "amalgam, a collection of heterogeneous components, a material-informatic entity whose boundaries undergo continuous construction and reconstruction" (Hayles, 1999, p. 3), which drives readers to reconsider human character.

As for unnatural spaces, Alber, in "Unnatural Spaces and Narrative Worlds", distinguishes the physically and logically impossible spaces. The former defies the law of nature with examples such as "shape-shifting locations, burning lakes, insubstantial castles, impossible planets, visions of the infinite universe, unnatural geographies, two-, one-, and nondimensional worlds, literal manifestations of internal processes, and houses that are bigger on the inside than they are on the outside" (Alber, 2013c, p. 62). The latter departs from the principle of noncontradiction with instances like the hallway is located on the north wall and on the west wall. Alber also puts forward seven ways to interpret the unnaturalness of spaces, they are blending or frame enrichment, categorizing unnatural spaces to certain literary genres, attributing them to somebody's interiority, connecting them with certain themes, relating them with satire or allegory, and including them within a transcendental realm. In Unnatural Narrative: Impossible Worlds in Fiction and Drama, Alber (2016) once again discusses the unnatural spaces. This time, Alber distinguishes the unnatural spaces where the interior exceeds the exterior, the entities in the storyworld externalized and materialized from internal states, unnatural geographies in which different real-world locations have been fused into a new whole or actual places and their traits have been altered and are no longer recognizable, and the storyworld whose boundaries can be transgressed and thus two different ontological domains interact. 
In terms of unnatural time lines, Richardson (2000), in "Narrative Poetics and Postmodern Transgression: Theorizing the Collapse of Time, Voice, and Frame", has dug out the anti-mimetic time arrangement. They include "circular" fiction which returns to its own beginning and thus continues infinitely, "contradictory" fiction in which incompatible and irreconcilable versions of the story are set forth, "antinomic" fiction whose narrative move backward in time, "differential" fiction in which time is passing at different rates, "conflated" fiction in which the "separate" times commence on melting or bleeding into each other, and "dual or multiple" fiction in which different plotlines, though beginning and ending at the same moment, nevertheless take different numbers of days to unfold.

Whereas Heinze (2013), in "The Whirligig of Time: Toward a Poetics of Unnatural Temporality", touches unnatural time lines on both the level of story and that of discourse. On the former level, unnatural temporality most often occurs in scenarios of time travel, time loops, time reversals, and diverging or alternative timelines. On the latter level, it happens in scenarios which employ temporal reversals of some kind or other, nonlinearity or fragmentation, future tense, and denarration. What's more, in Unnatural Narrative: Impossible Worlds in Fiction and Drama, Alber also discusses the unnatural temporality. He distinguishes retrogressive time lines which denotes the story itself runs backward in time, eternal temporal loop or what can be called circular temporalities, the fusing of distinct temporal realms which means "narratives question the assumption that the borders between the past, the present, and the future are fixed and impenetrable" (Alber, 2016, p. 165), narratives with ontological plural time which refers to the fictions that "violate the principle of noncontradiction by representing mutually exclusive story versions or event sequences so that time is fragmented into multiple (logically incompatible) itineraries" (Alber, 2016, p. 172), and coexisting story times which equals to "differential" time put forward by Richardson.

Unnatural emotions are raised by Chinese scholar Biwu Shang. In Unnatural Narrative across Borders: Transnational and Comparative Perspectives, Shang (2019) puts forward this new unnatural aspect which has not been touched upon by other unnatural narratologists. Based on the definition of unnatural narrative put forward by Alber, Shang distinguishes physically impossible emotions, logically impossible emotions, and humanly impossible emotions. The first one refers to "those emotions that have little to do with the real world around us, transgress the boundaries between the real world and the fictional world" (Shang, 2019 , p. 86). For instance, human beings' ardent love for animals is physically impossible. The second one denotes "those emotions that go against principles or rules governing the real world" (Shang, 2019, p. 86). For example, a corpse's telling how he feels in the process of his death is logically impossible. The last type deals with "those emotions that are mainly produced by those nonanthropological entities in narrative works" (Shang, 2019, p. 87).

Unnatural minds have been discussed by Alber et al. (2010) in "Unnatural Narratives, Unnatural Narratology: Beyond Mimetic Models". They point out that the unnaturalness may appear on the level of the story (cf. unnatural minds of characters) and the level of the narrative discourse. They cover the analysis of hetero- and homodiegetic narrator with zero focalization and heterodiegetic narrator with internal focalization. Alber, in 
"Pre-Postmodernist Manifestations of the Unnatural: Instances of Expanded Consciousness in 'Omniscient' Narration and Reflector-Mode Narratives", once again attaches importance to impossible representations of minds. Not only does he cover the unnaturalness of the omniscient narrators' reading other characters' minds through "psychonarration, free indirect discourse, or direct thought" (Alber, 2013a, p. 145), but he also copes with the unnaturalness of the covert narrative voice's mind-reading ability. The unnaturalness is demonstrated when the covert narrative medium is somehow able to know and tell readers exactly what the characters think and feel. This is equal to what Genette calls heterodiegetic narration with internal focalization. Furthermore, in "Unnatural Minds", Iversen (2013) purports that "[a]n unnatural mind is a presented consciousness that in its functions or realizations violates the rules governing the possible world it is part of in a way that resists naturalization or conventionalization" (p. 97). He narrows the scope and focuses on one type, namely the impossible mind which is "a mind that is biologically or logically impossible, such as mindreading mind, a deceased mind, a radically metaleptic mind, or a mind running without the hardware that the human mind as we know it is nested in" (Iversen, 2013, p. 104).

As for unnatural metalepses, the term "metalepsis" originates from Genette's structuralist narratology and refers to "any intrusion by the extradiegetic narrator or narratee into the diegetic universe (or by diegetic characters into a metadiegetic universe, etc.), or the inverse" (Genette, 1980, p. 234-235). In other words, it denotes the transgression of the "sacred frontier between two worlds, the world in which one tells, the world of which one tells" (Genette, 1980, p. 236). Richardson (2000), in "Narrative Poetics and Postmodern Transgression: Theorizing the Collapse of Time, Voice, and Frame", has mentioned that many postmodern experimental fictions' frames have been broken. Such kind of frame-breaking has been studied further by Jeff Thoss in "Unnatural Narrative and Metalepsis: Grant Morrison's Animal Man". Thoss (2011) distinguishes three types of transgression; they are transgressions between a story world and another (imaginary) world, feigned transgressions between a story world and reality, and transgressions between story and discourse.

Different from Thoss, Ryan (2012) in "Impossible worlds" has uttered that these "manifestations of ontological impossibility are known in narratology as metalepsis" (p. 371) and the breaking of boundaries can be vertical or horizontal. In the same year, Bell and Alber in their article "Ontological Metalepsis and Unnatural Narratology" also deal with "unnatural metalepses". Not only do they make a classification (ascending metalepsis, descending metalepsis, and horizontal metalepsis) about ontological metalepsis, but also point out its functions and the ways to interpret it. Ascending metalepsis means "a fictional character or narrator jumps from an embedded storyworld to a hierarchically higher one" and descending metalepsis refers to "a narrator or a character jumps into an embedded storyworld or an author jumps from the actual world into the storyworld" (Bell \& Alber, 2012, p. 167-168). Horizontal metalepsis, different from the former vertical types, is equivalent of transfictionality which denotes that a character in one fiction enters into another fiction (not series type). Based on the possible-world theory, Bell and Alber (2012) differentiate transworld identity and counterparthood in unnatural metalepses, and further put forward 5 thematic uses of ontological metalepsis, they are "exposing escapism, critiquing the abuse of 
power, highlighting the dangers of fiction, exemplifying mutual understanding, and, finally, illustrating confrontations with creators or their loss of control over their own creations" (p. 186).

In terms of unnatural acts of narration, Alber et al. (2010), in "Unnatural Narratives, Unnatural Narratology: Beyond Mimetic Models", suppose that it includes "physically, logically, mnemonically, or psychologically impossible enunciations" (p. 124). Taking the example of Poe's Tell-Tale Heart, they point out that the convergence of impersonal speech in the speech of both the enunciating and the enunciated subject eliminates the distinction between "narrated I" and "narrating I", and between time of the narrated and time of narration. In "Implausibilities, Crossovers, and Impossibilities: A Rhetoric Approach to Breaks in the Code of Mimetic Character Narration", Phelan (2013) touches upon three kinds of unnatural character narration, they are paralepsis, crossover narration, and simultaneous present-tense narration. Different from the rest two, the second one, to Phelan's knowledge, has not yet been touched upon before. As for crossover narration, Phelan (2013) finds that:

[A] uthor links the narration of two independent sets of events by transferring the effects of the narration of one to the narration of the other so that, for example, the affective responses evoked by the narration of one set of events will influence not just the audience's perception of the other set of events but the motivation of characters involved in those events. (p. 168-169)

Phelan takes Fitzgerald's novel The Great Gatsby as a case in point: the character narrator Nick's anxious walking directly into Gatsby's house cannot be explained unless we relate it to the previous intervening narration about Wilson's activities and Gatsby's movements and likely thoughts.

Phelan (2013) also raises 6 reasons why readers fail to notice these departures from the mimetic code. They include "Rule of Duration" (the briefer the break, the less likely it is to be noticed), "Rule of Partial Continuity" (when the break is restricted to one aspect of the narration, it is less likely to be noticed), "Rule of Self-Assurance" (if the character narrator does not call attention to the break, it is less likely to be noticed), "Rule of Temporal Decoding" (if the break in the code is detectable right away, it is more likely to be noticed than if it is not detectable until later in the narrative progression), "the Value-Added Meta-Rule" (the break will be overlooked if it enhances the reading experience which cannot be obtained without the break), "The Story-over-Discourse Meta-Rule" (the break will be overlooked if it enhances readers' mimetic engagements with the story).

As for unnatural narrator, it has triggered lots of scholars' interest. For example, Richardson (2000), in "Narrative Poetics and Postmodern Transgression: Theorizing the Collapse of Time, Voice, and Frame", claims that unnatural narrators include "fraudulent narrator" who obviously cannot be producing the narration he or she pretends to be giving voice to, "contradictory narration" which negates narrator's ordinary function to relate a single, intelligible story, "conflated narrators" who merge and blend into one another without any signal or explanation, "incommensurate narrators" who cannot be the single source of the heterogeneous voices of the text, and "dis-framed narrators" who move from one ontological 
level of the text to another in a way that is impossible outside of fiction.

In his book Unnatural Voices: Extreme Narration in Modern and Contemporary Fiction, Richardson (2006) continues to deal with unnatural voices, which is very obvious from the book name. This time, his analysis is very comprehensive, covering second-person narration which can be further divided into the 'standard', the 'hypothetical', and the 'autotelic' second person. The first refers to the designation of the protagonist as 'you'. And the second type employs the guidebook style to recount a narrative. As for the last type, it employs a direct address to the actual reader or the narratee. Richardson also discusses the "we" narration and classifies them, based on the degree to which they differentiate from the poetic of realism, into conventional, standard, nonrealistic, and anti-mimetic ones. He notices that the special 'we' narration denotes characters' fluctuating between "isolated individualism and a more collective consciousness" (Richardson, 2006, p. 38). What Richardson also delves into is that "we" narration is emblematic of the unity among implied author, authorial audience, and characters.

One interesting point concerning unnatural voice which has been dug out by Richardson is multiperson narration. It includes centrifugal one that "juxtaposes storytelling from first person, third person, and still other perspectives" and centripetal one in which "genuinely or apparently distinct voices are either contained within a single mind or collapsed into another voice" (Richardson, 2006, p. 71). Richardson also signals that there are three extreme forms of narration: the interlocutor, denarration, and the permeable narrator. The interlocutor is "a disembodied voice that poses questions which the narrative goes on to answer" (Richardson, 2006, p. 79). It is a parody of dialogue. Denarration refers to a narrative negation in which the narrator negates what he claims earlier. Its effects are variable. Either it can play an insignificant role in the overall text or it can change thoroughly the story's nature and reception. The permeable narrators are "distinct figures who merge and blend into one another without any signal or explanation, and are thus a large-scale extension of vagrant thoughts of one character that somehow find their way into the consciousness of another" (Richardson, 2006, p. 104-105).

Ryan, in "New Wine in Old Bottles? Voice, Focalization, and New Writing", not only realizes the unnaturalness of omniscient narrator but also attaches importance to the unnaturalness of neutral narrative, especially in the case of first-person. Ryan (2001) finds that:

[First-person neutral narrative] constitutes a new schema which is entirely nonnatural since real-life autobiography necessarily resorts to memory and has access to internal consciousness of the narrator. The refusal to provide motivation for the first-person narrator's actions in neutral narrative therefore makes for a drastic violation of real-life parameters. (p. 625)

Ryan (2001) also notices that even though narratives of present tense have become very common nowadays, some present-tense narratives, "especially instances of what Stanzel called 'dying in the first person' certainly invoke a departure from realist frames" ( $p$. 625-626). Furthermore, Ryan (2001) discovers that heterodiegetic extradiegetic narrator with internal focalization is extremely unnatural and its unnaturalness lies in the "narrator's 
narrating the thoughts of the protagonist in his own language but as if the character had become the narrator" (p. 629), which is often neglected by readers.

In Unnatural Narrative: Impossible Worlds in Fiction and Drama, Alber (2016) likewise discusses the unnatural narrator, including the animal narrator, speaking body parts and object narrators, the telepathic first-person narrators who can read others' mind, the voice in you-narratives, the omniscient narrator, and the reflector-mode narratives of literary modernism. Animal narrators are numerous in fiction. To name a few, a rebellious horse serves as the narrator in John Hawkes's novel Sweet William: A Memoir of Old Horse. Likewise, object narrators are favored by novelists, especially eighteenth-century writers who choose coins, sofa, slippers, building, coat, atom, banknote, corkscrew, coach, watch, pins, ostrich feather, and others as the narrator of their works. These unnatural narrators have one thing in common, that is they are commodities which can be purchased, lost, found, given, and bartered. Thus, these narratives provide a critical angle on "the circulation of objects in the public sphere" and "the development of capitalism" (Alber, 2016, p. 74). No matter what kinds of unnatural narrators they are, Alber (2016) notices that they "involve conventionalized types of antirealism", like "beast fable, children's literature, circulation novels, omniscient and reflector-mode narratives" (p. 103).

Nielsen (2004), in "The Impersonal Voice in First-Person Narrative Fiction", probes into the unnatural aspect of the first-person narrators. Nielsen focuses on the "transgression of the knowledge frame of the narrating-I". One striking aspect is the homodiegetic narrators enjoy zero focalization and know more than what they could know, with Ishmael in Moby-Dick being a representative example. Considering this transgression, Nielsen (2004) designates "impersonal voice" to the voice that "neither belongs to the narrating-I nor to the narrated-I" (p. 139).

Heinze (2008), in "Violations of Mimetic Epistemology in First-Person Narrative Fiction" also deals with the unnaturalness of the first-person omniscient narrative. Heinze supports Manfred Jahn's opinion that first-person omniscience can be called "paralepsis". Heinze also makes a tentative typology of paraleptic which includes illusory paralepsis, humor paralepsis, mnemonic paralepsis, global paralepsis, and local paralepsis. The former three kinds, Heinze (2008) maintains, are natural due to "the final revelation of the (realistic) source of the narrator's unusual knowledge", self-reflexive and facetious acknowledgement of its own impossibility, and the narrators' "unconvincingly flawless (inhuman)" (p. 285-286) memory. Only the last two types are unnatural. Their violations of mimetic epistemology lie in the "naturalness contained within the non-natural frame" and "non-naturalness contained within the natural frame" (Heinze, 2008, p. 286). His minute category of paralepsis enables him to concentrate on the true violations and also renders him the chance to challenge Nielsen's general claim about the unnaturalness regarding the first-person omniscient narrative.

\subsection{Interpretive Strategies of Unnatural Narrative}

Just as Alber et al. (2010) claim that "the study of unnatural narrative seeks to describe the ways in which projected storyworlds deviate from real-world frames, and, in a second step, it then tries to interpret these "deviations"' (p. 116). 
Several narratologists put forward reading strategies to unnatural narrative. For instance, in "Impossible Worlds", Ryan (2012) presents three kinds of "naturalizing" interpretations and three ways when naturalizing explanations fail. The first three include "mentalism", "figural interpretation", and "many-worlds and virtualization". The rest three refer to "dream-like reality", "Swiss-cheese world", and "meta-textualism and do it yourself". In "Impossible Storyworlds - and What to Do with Them", Alber (2009), based on pre-existing cognitive parameters, expresses five ways to interpret unnatural narrative, they are "reading events as internal states", "foregrounding the thematic", "reading allegorically", "blending scripts" and enriching frame. In "Unnatural Narratology: The Systematic Study of Anti-Mimeticism" and Unnatural Narrative: Impossible Worlds in Fiction and Drama, Alber (2013b, 2016) expands the aforementioned five reading strategies to nine navigational strategies. Apart from the former five, the added ones are relating it to satire, "assuming that they are part of a transcendental realm", "do it yourself", and "the Zen way reading"2. Unlike Alber, Nielsen (2013), in "Naturalizing and Unnaturalizing Reading Strategies: Focalization Revisited", comes up with the unnaturalizing reading strategies which "resist the application of real-world limitations to all narratives and refrain from limiting interpretations to what is possible in literal communicative acts and representational models" (p. 8).

\section{Conclusion}

Unnatural narrative is an increasingly important theory in literary criticism. Its significance has been summarized by Shang (2019) in the following five aspects: (1) it can enrich contemporary narrative theory and display the unnaturalness of many narratives; (2) it can reveal the fictional nature of literature; (3) it has heuristic values for the rewriting of literary history; (4) it is extremely useful for realizing certain ideological purposes; (5) it exerts positive effects upon human cognition. Indeed, unnatural events and scenarios significantly broaden the cognitive horizon of human awareness.

Nevertheless, only when we get a systematic knowledge about the definition, the manifestations, and the interpretative strategies of unnatural narrative can we utilize this theory to analyze the non- and anti-mimetic texts which are ubiquitous in postmodern literature.

\section{Acknowledgments}

My wholehearted gratefulness is forwarded to my supervisor Professor Kairui Fang of Guangdong University of Foreign Studies. Besides, my cordial gratitude also goes to Professor Qian Cheng of Jinan University who was my supervisor in my postgraduate study. Their enlightening suggestions were enormously instructive for me to finish this literature review.

\section{References}

Alber, J. (2009). Impossible storyworlds - and what to do with them. Storyworlds: A Journal of Narrative Studies, 1, 79-96. https://doi.org/10.1353/stw.0.0008 
Alber, J. (2013a). Pre-postmodernist manifestations of the unnatural: Instances of expanded consciousness in 'omniscient' narration and reflector-mode narratives. Zeitschrift für Anglistik und Amerikanistik, 61(2), 137-153. https://doi.org/10.1515/zaa.2013.61.2.137

Alber, J. (2013b). Unnatural narratology: The systematic study of anti-mimeticism. Literature Compass, 10(5), 449-460. https://doi.org/10.1111/lic3.12065

Alber, J. (2013c). Unnatural spaces and narrative worlds. In J. Alber, H. S. Nielsen, \& B. Richardson (Eds.), A poetics of unnatural narrative (pp. 45-66). Columbus: The Ohio State University Press.

Alber, J. (2016). Unnatural narrative: Impossible worlds in fiction and drama. Lincoln and London: University of Nebraska Press. https://doi.org/10.2307/j.ctt1d4v147

Alber, J., \& Heinze, R. (Eds.). (2011). Unnatural narratives, unnatural narratology. Berlin and New York: de Gruyter. https://doi.org/10.1515/9783110229042

Alber, J., Iversen, S., Nielsen, H. S., \& Richardson, B. (2010). Unnatural narratives, unnatural narratology: Beyond mimetic models. Narrative, 18(2), 113-136. https://doi.org/10.1353/nar.0.0042

Alber, J., Nielsen, H. S., \& Richardson, B. (Eds.). (2013). A poetics of unnatural narrative. Columbus: The Ohio State University Press.

Bell, A., \& Alber, J. (2012). Ontological metalepsis and unnatural narratology. Journal of Narrative Theory, 42(2), 166-192. https://doi.org/10.1353/jnt.2012.0005

Genette, G. (1980). Narrative discourse - an essay in method. New York: Cornell University Press.

Hayles, N. K. (1999). How we became posthuman: Virtual bodies in cybernetics, literature, and informatics. Chicago: University of Chicago Press.

https://doi.org/10.7208/chicago/9780226321394.001.0001

Heinze, R. (2008). Violations of mimetic epistemology in first-person narrative fiction. Narrative, 16(3), 279-297. https://doi.org/10.1353/nar.0.0008

Heinze, R. (2013). The whirligig of time: Toward a poetics of unnatural temporality. In J. Alber, H. S. Nielsen, \& B. Richardson (Eds.), A poetics of unnatural narrative (pp. 31-44). Columbus: The Ohio State University Press.

Herman, D. (2013). Storyworlds- and storyworlds: In transition. Storyworlds: A Journal of Narrative Studies, 5(5), vii-xi.

Iversen, S. (2013). Unnatural minds. In J. Alber, H. S. Nielsen, \& B. Richardson (Eds.), A poetics of unnatural narrative (pp. 94-112). Columbus: The Ohio State University Press.

Nielsen, H. S. (2004). The impersonal voice in first-person narrative fiction. Narrative, 12(2), 133-50. https://doi.org/10.1353/nar.2004.0002

Nielsen, H. S. (2013). Naturalizing and unnaturalizing reading strategies: Focalization 
revisited. In J. Alber, H. S. Nielsen, \& B. Richardson (Eds.), A Poetics of unnatural narrative (pp. 67-93). Columbus: The Ohio State University Press.

Phelan, J. (2013). Implausibilities, crossovers, and impossibilities: A rhetoric approach to breaks in the code of mimetic character narration. In J. Alber, H. S. Nielsen, \& B. Richardson (Eds.), A poetics of unnatural narrative (pp. 167-184). Columbus: The Ohio State University Press.

Richardson, B. (2000). Narrative poetics and postmodern transgression: Theorizing the collapse of time, voice, and frame. Narrative, 8(1), 23-42.

Richardson, B. (2006). Unnatural voices: Extreme narration in modern and contemporary fiction. Columbus: The Ohio State University Press.

Richardson, B. (2015). Unnatural narrative: Theory, history, and practice. Columbus: The Ohio State University Press.

Ryan, M. L. (2001). New wine in old bottles? Voice, focalization, and new writing. New Literary History, 32(3), 619-638. https://doi.org/10.1353/nlh.2001.0033

Ryan, M. L. (2012). Impossible worlds. In J. Bray, A. Gibbons, \& B. McHale (Eds.), The Routledge companion to experimental literature (pp. 368-379). London: Routledge.

Shang, B. (2019). Unnatural narrative across borders: Transnational and comparative perspectives. New York: Routledge. https://doi.org/10.4324/9780429458941

Thoss, J. (2011). Unnatural narrative and metalepsis: Grant Morrison's Animal Man. In J. Alber \& R. Heinze (Eds.), Unnatural narratives, unnatural narratology (pp. 189-219). Berlin and New York: de Gruyter. https://doi.org/10.1515/9783110229042.189

\section{Notes}

Note 1. While in dream-like realities the entire fictional world is filled with contradictions, in the case of Swiss-cheese world the irrational is contained in delimited areas that pierce the texture of the fictional world like the holes of a Swiss cheese.

Note 2. The Zen way of reading presupposes an attentive and stoic reader who repudiates the earlier explanations and simultaneously accepts both the strangeness of unnatural scenarios and the feelings of discomfort, fear, worry, and panic that they might evoke in her or him.

\section{Copyright Disclaimer}

Copyright for this article is retained by the author(s), with first publication rights granted to the journal.

This is an open-access article distributed under the terms and conditions of the Creative Commons Attribution license (http://creativecommons.org/licenses/by/4.0/). 